\title{
SEDIMENTOLOGICAL SIGNATURES OF SUB-ICE-SHELF CIRCULATION: AN EXAMPLE FROM VINCENNES BAY, EAST ANTARCTICA
}

\author{
by Peter T. Harris
}

(with one table and four text-figures)

Harris, P.T., 2000 (31:v): Sedimentological signatures of sub-ice-shelf circulation: An example from Vincennes Bay, East Antarctica. In Banks, M.R. \&Brown, M.J. (Eds): TASMANIA AND THESOUTHERNOCEAN.Pap. Proc. R. Soc. Tasm. 133(3): 57-62. https://doi.org/10.26749/rstpp.133.2.57 ISSN 0080-4703. Antarctic CRC and Australian Geological Survey Organisation, GPO Box 252-80, Hobart, Tasmania, Australia 7001.

Two cores of Holocene sediment, collected on opposite flanks of the Vanderford Glacier in Vincennes Bay, while representing contemp•raneous sedimentation, have different sediment characteristics, with a relatively lower biogenic content on the western side than on the east. These sedimentological signatures are attributed to differences in circulation patterns. Circulation involves landward flow at depth, bringing warmer ocean water into contact with the base of the glacier. This water becomes mixed with fresh meltwater and suspended glacial sediments to form a buoyant plume that rises and flows in a seaward direction under the ice shelf. The landward and seaward flows are deflected to the left in the Southern Hemisphere by the Coriolis effect and, hence, are laterally separated. This pattern explains thedifferences observed in sediments deposited on opposite sides of the ice shelf in front of the Vanderford Glacier and may be a common feature beneath all large-scale ice shelves.

Key Words: Holocene sediments, ice shelves, circulation, radiocarbon dates.

\section{INTRODUCTION}

Water circulation under a floating ice shelf involves landward flow at depth, which brings warmer ocean water into contact with the base of the glacier. This water is mixed with fresh meltwater, which forms a buoyant mixture that rises to the surface while flowing in a seaward direction (fig. 1). Recent modelling work by Williams et al. (1998) has shown that the landward and seaward flows are deflected to the left by the Coriolis force and, hence, the flows tend to be laterally separated (fig. 1).

Although there have been several facies models proposed for the deposition of sediments under floating ice shelves (Domack \& Harris 1998), only limited reference has been made to the effects of sub-ice-shelf circulation. The sedimentary implications of the lateral separation of subice-shelf flow have not been considered. The near-bed velocity of such flows may be significant with respect to bedload sediment transport. Recently collected sidescan sonar data show large-scale (of the order of $50 \mathrm{~m}$ wavelength) bedforms on the middle shelf of Prydz Bay, which may have been produced by sub-ice-shelf flow when the Amery Ice shelf was advanced over the area during the last glacial maximum (O'Brien et al. 1999). These dunes are consistently oriented with their steeper lee slope facing landwards, which is consistent with their formation in association with landward-flowing bottom currents such as occur under floating ice shelves (fig. 1).

The aim of the present paper is to examine the sedimentological signatures that might be generated by water and sediment circulation patterns underneath and directly in front of floating ice shelves. Data on sediment properties are assessed in relation to the inferred circulation patterns beneath the floating ice shelf of the Vanderford Glacier in Vincennes Bay, East Antarctica.

\section{METHODS}

Gravity cores were collected in 1997 at six locations in Vincennes Bay using the RV Aurora Australis (AGSO cruise number 186, Harris et al. 1997: fig. 2). The coring device consisted of a 1 tonne bomb connected to $6 \mathrm{~m}$ length by $10 \mathrm{~cm}$ diameter core barrels ( $9 \mathrm{~cm}$ diameter PVC core liner). Cores $186 / 5$ GC7 and 186/6GC8, collected $10 \mathrm{~km}$ from the front of the Vanderford Glacier, were used in the present study (fig. 2).

Magnetic susceptibility was measured on whole cores at $2 \mathrm{~cm}$ intervals, using a Bartington MS2-C meter connected to a $10 \mathrm{~cm}$ diameter coil. Data were corrected for instrument drift and end-of-core effects. Visual descriptions of the split cores were prepared taking note of sediment texture, colour, fossil content, apparent grain size, sorting and sedimentary structures. A preliminary report, giving descriptive information and details of differences in diatom content of the cores, was presented by Harris et al. (1997).

Separate subsamples taken at $5-10 \mathrm{~cm}$ intervals downcore were analysed for biogenic opal content, using the method outlined by Mortlock \& Froelich (1989). Total organic carbon (TOC) content was determined on splits of these samples by the combustion method at the Chemistry Department, University of Tasmania. Eleven AMS C-14 dates were obtained on bulk organic carbon with dilute $\mathrm{HCl}$ pre-treatment by the Institute of Geological and Nuclear Sciences, Lower Hutt, New Zealand.

\section{RESULTS}

\section{Radiocarbon Dating and Core Chronologies}

Details of the radiocarbon ages determined are listed in table 1. The surface ages for the cores are quite large, 9393 years for 5GC7 and 4114 years for 6GC8. These ages are explained from palynology preparations that were made for 


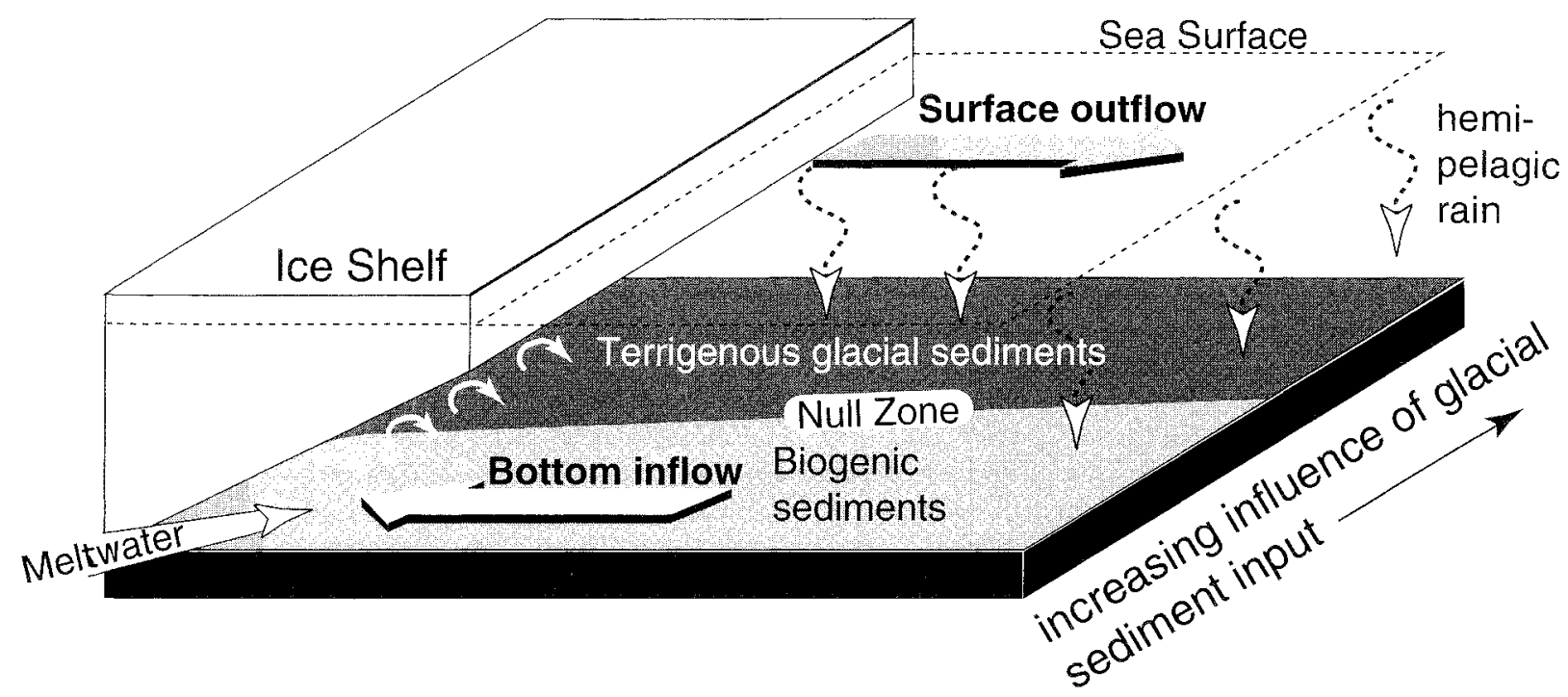

FIG.I - Schematic diagram showing the circulation pattern of water under a floating ice shelf. Landward flow at depth transports biogenic sediments under the ice shelf and brings warm ocean water into contact with the base of the glacier. This water is mixed with fresh meltwater containing suspended terrigenous sediments, which forms a buoyant plume that rises to the surface while flowing in a seaward direction. Flows are deflected to the left by the Coriolis force, giving rise to a lateral separation of flow. A "null zone" (Domack \& Harris 1998) exists in bottom sediment deposits, where the biogenic-marine supply is equal to the glacial-terrigenous supply.

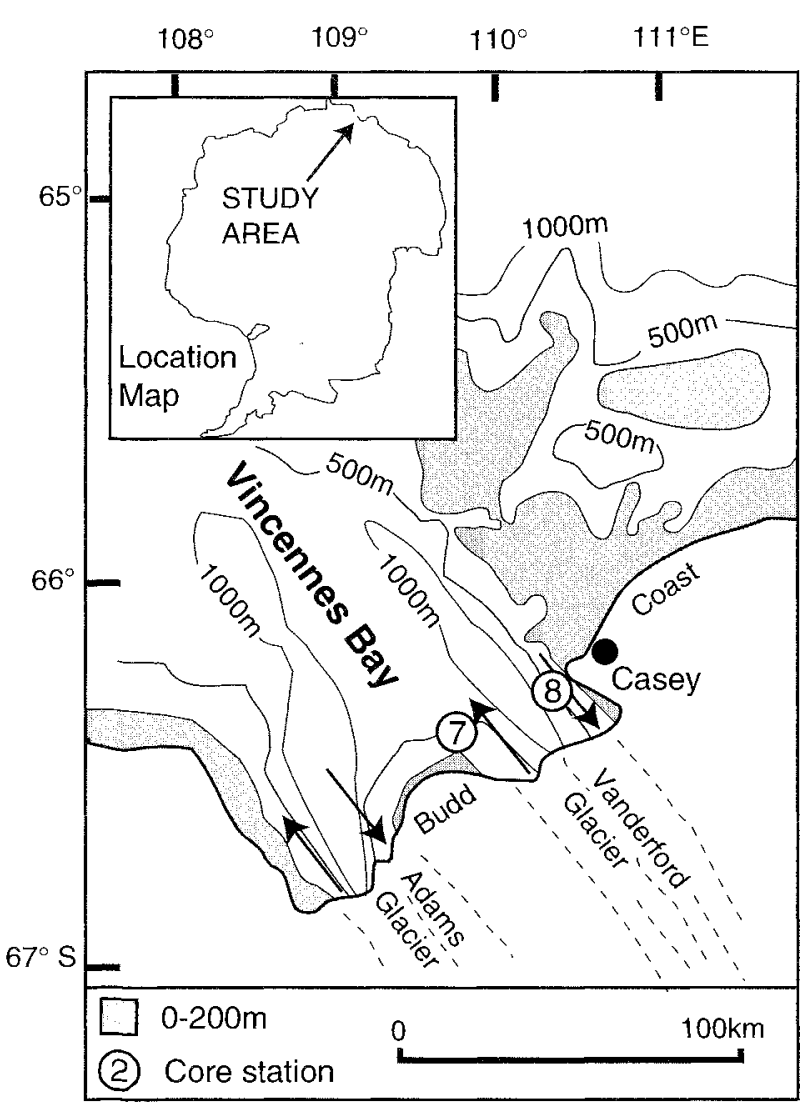

$F I G .2$ - Location map showing the positions of cores $5 G C 7$ and $6 G C 8$, located in $1200 \mathrm{~m}$ and $1740 \mathrm{~m}$ water depth respectively, near the calving front of the Vanderford Glacier. three samples in each of the cores, which showed the widespread occurrence of Eocene dinoflagellate cysts (A. McMinn, pers. comm.). Hence, the apparent surface ages are related to contamination by recycled ancient organic matter, which dilutes the ${ }^{14} \mathrm{C}$ content of TOC and affects the AMS radiocarbon age (Harris et al. 1996; table 1). In order to derive a chronology for the cores, the surface ages (assumed real age 0 years) were subtracted from the ages lower down in each core. This correction appears to be justified because

(1) the recycled Eocene organic matter is apparent throughout the cores in palynology slides;

(2) all of the radiocarbon ages in core 6GC8 and the top three ages in core 5GC7 increase progressively down core, suggesting that the contamination factor is systematic; and (3) the opal, TOC and magnetic susceptibility time series are comparable between the two cores, using the radiocarbonderived timescale (see below).

\section{Core Profiles}

Core 5GC7 is divided into two separate units based on radiocarbon chronology and lithology. Radiocarbon dates from the upper $200 \mathrm{~cm}$ of this core (fig. 3, table 1) depict a consistent increase in age with depth, indicative of sedimentation rates of $23 \mathrm{~cm} / \mathrm{kyr}(0-100 \mathrm{~cm})$ and $10 \mathrm{~cm} / \mathrm{kyr}$ $(100-200 \mathrm{~cm})$. Between 100 and $200 \mathrm{~cm}$ the core exhibits abundant bioturbation structures, which are consistent with the slow accumulation rate calculated for this interval. The similarity in the radiocarbon ages below $200 \mathrm{~cm}$ suggests that an interval of rapid accumulation occurred, and the possibility exists that the bioturbated unit below $120 \mathrm{~cm}$ (fig. 3) includes one or more disconformities. The laminae that are common below $400 \mathrm{~cm}$ core depth (fig. 3) exhibit a sharp lower contact with an upper transitional boundary, indicative of turbidites. However, above $-200 \mathrm{~cm}$ the core 
TABLE 1

AMS ${ }^{14} \mathrm{C}$ ages for bulk organic carbon samples collected in Vincennes Bay, East Antarctica

\begin{tabular}{|c|c|c|c|c|c|}
\hline Core No. & Depth $(\mathrm{cm})$ & Age yr BP & \pm yrs BP & Corrected age* & Lab Ref. No. ${ }^{\dagger}$ \\
\hline \multirow[t]{6}{*}{$186 / 5 \mathrm{GC}^{*}$} & 1 & 9393 & 74 & 0 & NZA 8209 \\
\hline & 101 & 13705 & 78 & 4312 & NZA 8210 \\
\hline & 201 & 23580 & 160 & 14187 & NZA 8211 \\
\hline & 301 & 21500 & 120 & 12107 & NZA 8212 \\
\hline & 401 & 21910 & 120 & 12517 & NZA 8213 \\
\hline & 519 & 20730 & 120 & 11337 & NZA 8036 \\
\hline \multirow[t]{5}{*}{$186 / 6 \mathrm{GC}^{\$}$} & 1 & 4114 & 77 & 0 & NZA 8205 \\
\hline & 121 & 7408 & 68 & 3294 & NZA 8206 \\
\hline & 301 & 9322 & 62 & 5208 & NZA 8326 \\
\hline & 401 & 10993 & 74 & 6879 & NZA 8207 \\
\hline & 518 & 12250 & 80 & 8136 & NZA 8037 \\
\hline
\end{tabular}

* Corrected ages were determined by subtracting the surface age from all ages in each core.

"The laboratory reference numbers are from the New Zealand Institute of Geological and Nuclear Sciences, Rafter Radiocarbon Laboratory, Lower Hutt (NZA).

From $66^{\circ} 30.3^{\prime} \mathrm{S}, 109^{\circ} 57.1^{\prime} \mathrm{E}$.

§ From $66^{\circ} 22.0^{\prime} \mathrm{S}, 110^{\circ} 10.4^{\prime} \mathrm{E}$.

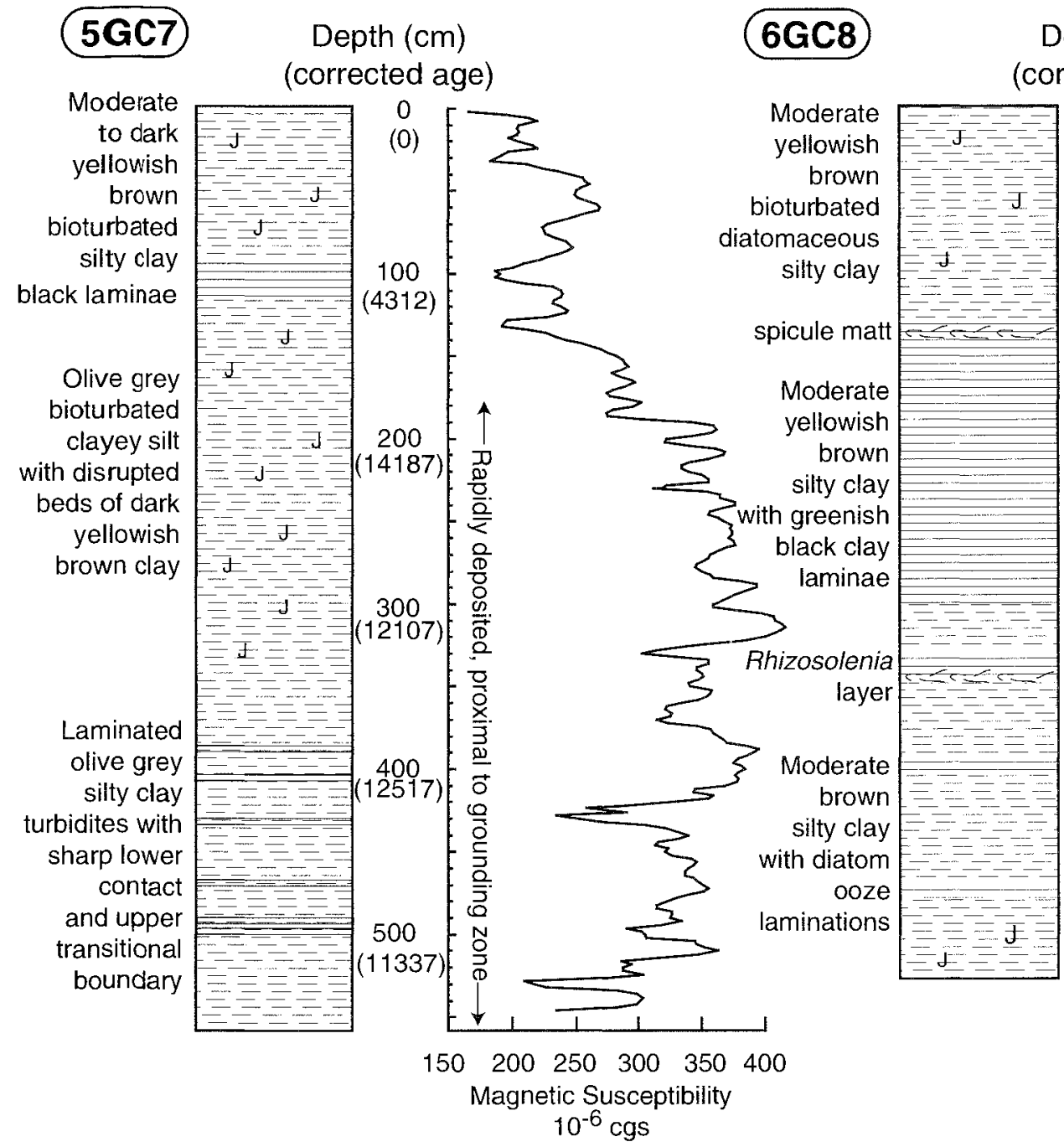

Depth $(\mathrm{cm})$ (corrected age)

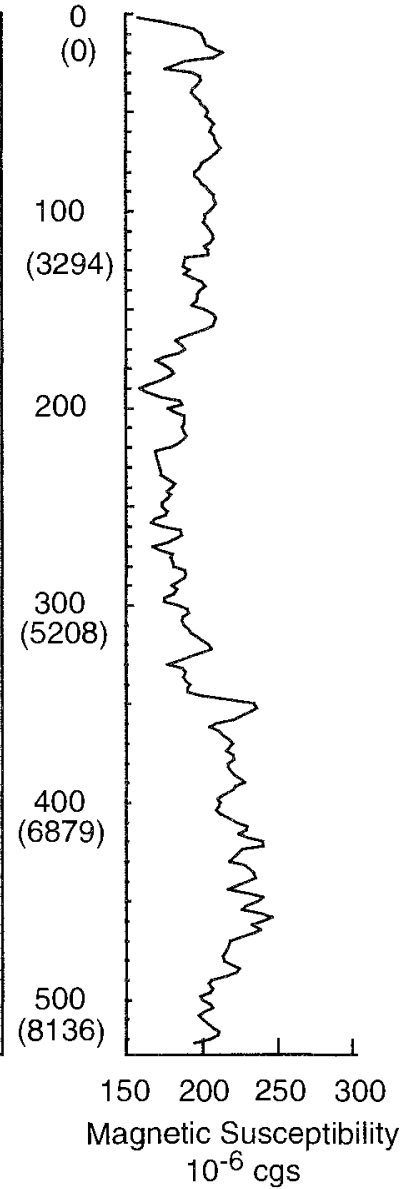

FIG. 3 - Visual core logs and magnetic susceptibility curves for cores $5 G C 7$ and $6 G C 8$ (modified from Harris et al. 1997, to include corrected radiocarbon dates). The presence of bioturbation (mottles and burrows) is shown by "J". 
appears to provide a reasonable radiocarbon chronology (table 1) and the profiles of TOC, opal and magnetic susceptibility over this time interval ( 0 to $-8 \pm 2 \mathrm{kyr} B P$ ) are considered here to represent a continuous time series (fig. 4).

Radiocarbon dates from core 6GC8 show a consistent increase down-core (fig. 3, table 1) and suggest a mean sedimentation rate of $64 \mathrm{~cm} / \mathrm{kyr}$ over the $520 \mathrm{~cm}$ length of the core. The upper $130 \mathrm{~cm}(0-3300 \mathrm{yrs} \mathrm{BP})$ of core $6 \mathrm{GC} 8$ is a moderate yellowish-brown, bioturbated, diatomaceous, silty clay (fig. 3). The opal, TOC and magnetic susceptibility time series for this interval (fig. 4) show that the sediment is low in TOC $(0.5-0.6 \%)$, low in biogenic silica $(10-$ $15 \%)$ and has a low accumulation rate of about $33 \mathrm{~cm} / \mathrm{kyr}$. Below $130 \mathrm{~cm}$ the core is moderate yellowish-brown, silty clay with greenish-black laminae containing abundant diatoms (fig 3). This interval is relatively high in TOC $(0.5-0.8 \%)$ high in biogenic silica $(15-30 \%)$ and has average sedimentation rates of from 60 to $94 \mathrm{~cm} / \mathrm{kyr}$ (figs 3, 4).

\section{DISCUSSION}

\section{Palaeoenvironmental Interpretation}

The shift from high TOC/opal and low magnetic susceptibility at $3.5-6 \mathrm{kyr} \mathrm{BP}$, to low TOC/opal and high magnetic susceptibility sedimentation after $3.5 \mathrm{kyr}$ BP (fig. 4), is paralleled by a shift from open-water diatoms (F. kerguelensis) to sea-ice diatoms ( $F$. curta; Harris et al. 1997). These changes imply colder conditions and/or more persistent sea ice in the late Holocene. This interpretation is consistent with results of workers from the Antarctic Peninsula (Shevenell et al. 1996, Leventer et al. 1996), who also inferred greater sea-ice cover for more of the year in the late Holocene. A mid-Holocene warm phase was described by Baroni \& Orombelli (1994) as a time of lower winter seaice coverage and the time of a "penguin maximum", followed by a period of increased sea-ice coverage in the late Holocene. A mid-Holocene climatic optimum period followed by late Holocene glacial advance has been documented in other onshore climate records from East Antarctica (Ingolfsson et al. 1998). Also, the Law Dome $\delta^{18} \mathrm{O}$ ice core records suggest that cooler mean annual and winter temperatures have occurred for the last 700 years (Morgan \& van Ommen 1997) and a contemporaneous decrease in winter snow accumulation at the Law Dome ice margin has been proposed (Goodwin 1996). The shift from biogenic to siliciclastic dominated sedimentation may be associated with an advance of the Vanderford and Adams Glacier system, consistent with the evidence for an advance of the Law Dome ice-sheet margin since 4000 yr BP (Goodwin 1996).

\section{Influence of Circulation Patterns on Sedimentation}

The records of changing sedimentation patterns observed in the cores are also related to water circulation and sediment transport patterns within Vincennes Bay. Core 6GC8 is located close to a broad, shallow shelf (fig. 2) which provides
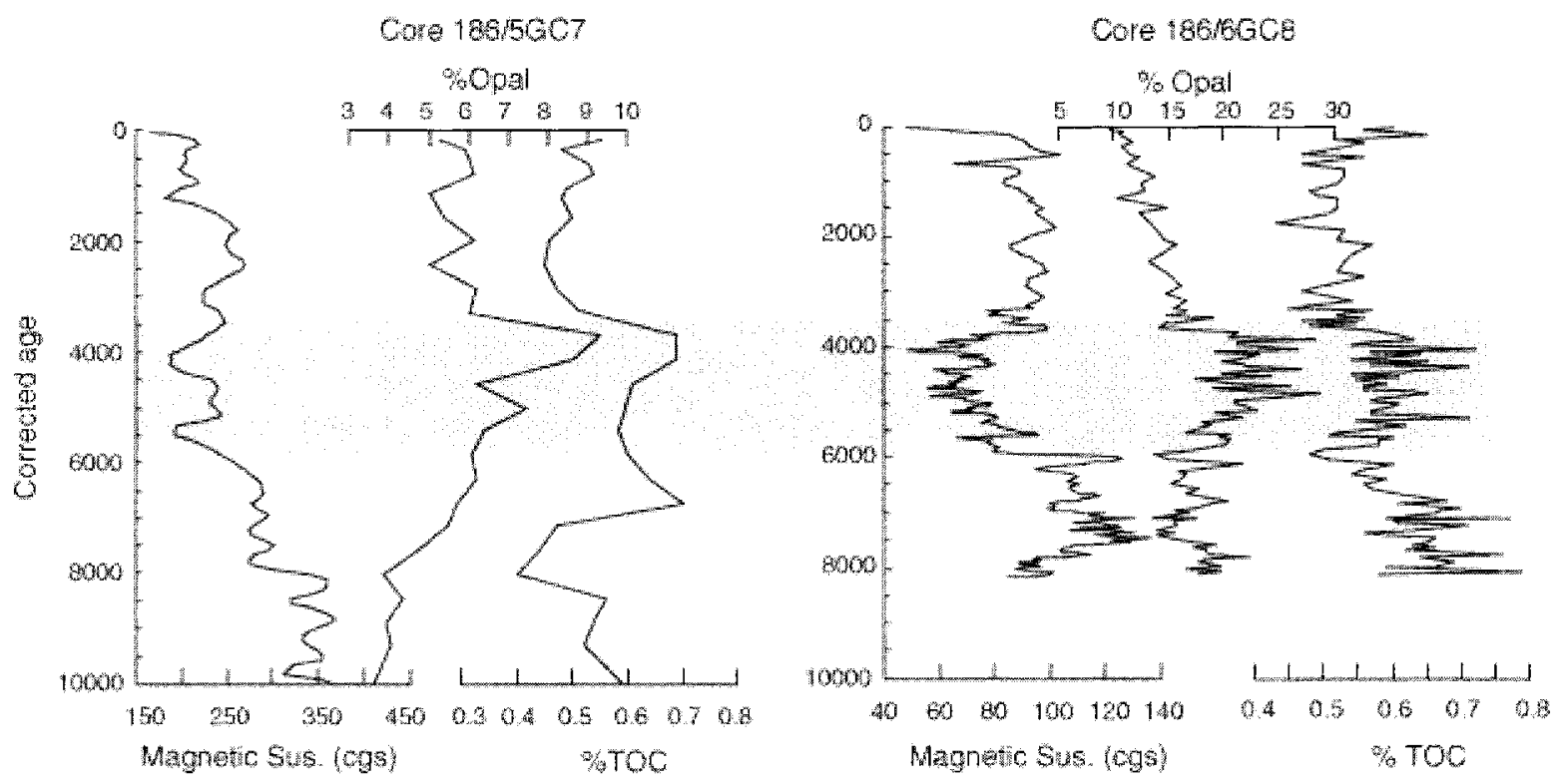

FIG. 4-Down-core profiles for cores $5 G C 7$ and $6 G C 8$, showing magnetic susceptibility, percentage opal and percentage TOC versus time. The shaded area illustrates that both cores contain a similar record showing a mid-Holocene (3.5-6 kyr BP) low in magnetic susceptibility (glacial terrigenous sediment) and high in TOC and opal content. Core $5 G C 7$ exhibits high absolute values of magnetic susceptibility, with a mean of $308 \pm 60 \times 10^{-6} \mathrm{cgs}$ and a maximum of $416 \times 10^{-6} \mathrm{cgs}$ at a depth of $310 \mathrm{~cm}$. Opal content is relatively low, with a mean value of $5.3 \pm 1.4 \%$, a maximum of $9.3 \%$ and a minimum of $3.5 \%$. TOC content is also low, with a mean value of $0.61 \pm 0.11 \%$, a maximum of $0.95 \%$ and a minimum of $0.40 \%$. Core $6 G C 8$ exhibits lower absolute values of magnetic susceptibility, with a mean of $90.6 \pm 18.5 \times 10^{-6} \mathrm{cgs}$ and a maximum of $136 \times 10^{-6} \mathrm{cgs}$ at a depth of $455 \mathrm{~cm}$. Opal content is relatively high, with a mean value of $17.6 \pm 4.1 \%$, a maximum of $28.7 \%$ and a minimum of $9.7 \%$. TOC content is similar to $5 \mathrm{GC7}$, with a mean value of $0.58 \pm 0.07 \%$, a maximum of $0.79 \%$ and a minimum of $0.43 \%$. 
a source of reworked biogenic and terrigenous sediments swept into the adjacent glacial trough by southeastwards flowing currents (Harris etal. 1997). This would explain the relatively higher sedimentation rate at core $6 \mathrm{GC} 8$ (mean of $64 \mathrm{~cm} / \mathrm{kyr}$ than that at $5 \mathrm{GC} 7(10-23 \mathrm{~cm} / \mathrm{kyr})$.

Another important factor is the sub-ice-shelf circulation and lateralflow separation pattern that might be expected under the floating ice shelf of the Vanderford Glacier (fig. 1). Such a circulation pattern would account for the relatively higher biogenic silica and TOC values found throughout core $6 \mathrm{GC} 8$ in comparison with core 5GC7. Whereas both core sites would experience hemipelagic sediment rain (fig. 1), core 6GC8 would be expected to have higher biogenic input, due to the landward current flow delivering mainly marine-derived biogenic sediments. In contrast, core $5 \mathrm{GC} 7$ would be expected to have higher terrigenous sediment input, due to the seaward flow delivering mainly glacially derived sediments (fig. 1). If the recycled Eocene dinoflagellate cysts are derived from this glacial terrigenous source, it would account for greater TOC contamination and, hence, explain the greater apparent surface radiocarbon age in core $5 \mathrm{GC} 7$ compared with core $6 \mathrm{GC} 8$ (table 1). However, the meltwater may itself provide a source of ${ }^{14} \mathrm{C}$-dead organic matter and dissolved carbon.

One core studied by Domack et al. (1989) collected off Adélie Land had a surface radiocarbon age of about 5500 years, which these workers attributed to old carbon released in glacial meltwater. The actual source of the ${ }^{14} \mathrm{C}$ depleted material is unclear. It probably cannot be attributed to $\mathrm{CO}_{2}$ gas in air bubbles trapped in the ice, as this concentration is far too low. It may be that dissolution of ancient calcareous rocks under the grounded ice sheet provides a source of the ${ }^{14} \mathrm{C}$ depleted meltwater. Such a mechanism was proposed by Heier-Nielsen et al. (1995) to explain relatively large ${ }^{14} \mathrm{C}$ surface sediment ages in some samples from Danish fiords. Goodwin (1988) studied basal meltwater near Casey Station (fig. 2) and found that it had a high solute load, with concentrations of $\mathrm{HCO}_{3}$ of 0.00352 mol l-1, which is about 1.5 times that of normal seawater. The prediction of the sub-ice-shelf flow model is that one should encounter greater meltwater flow near the surface along the left flank of floating ice shelves, facing seawards (fig. 1). Consequently, one would expect to observe a corresponding increase in ${ }^{14} \mathrm{C}$ dilution in the surface waters on the left (western) flank of the Vanderford Glacier, which is consisrent with the ${ }^{14} \mathrm{C}$ age of the surface sediment being greater for core $5 \mathrm{GC} 7$ (9393 yrs) than core 6GC8 (4114 yrs - table 1$)$.

\section{Refinement of Sub-ice-shelf Facies Models}

In their review of sub-ice-shelf sedimentary facies, Domack \& Harris (1998) described a succession of facies in a seaward direction, from sub-ice-shelf beneath a basal debris zone, sub-ice-shelf distal to a debris zone, calving-line transition and, finally, to the open marine facies. At some distance seawards of the grounding line, beneath wide (>10 km) floating ice shelves, theoretically there exists a "null zone" in sedimentation, where the volume of fine-grained, glacialterrigenous sediment deposited is equal to the fine-grained hemipelagic component advected landwards under the ice shelf by recirculating currents. This landward advected marine sediment includes diatoms and other phytoplankton together with fine-grained, iceberg-rafted debris released in the open marine setting (Domack \& Harris 1998).

Based on the lateral separation model (fig. 1), it is evident that this "null zone" does not exist in only two dimensions. Rather, it should trend obliquely across the ice shelf or even subparallel to the axis of ice flow (fig. 1). Its orientation may also vary temporally, as a function of meltwater discharge and/or other oceanographic factors associated with the density-driven, sub-ice-shelf circulation. Hence, the sub-ice-shelf facies succession, and particularly the "null zone" described above, will exhibit spatial and temporal variability.

\section{CONCLUSIONS}

A new oceanographic model for circulation under floating ice shelves provides the basis for refinement of existing subice-shelf sedimentation models. Ice shelves that are large enough in scale for the Coriolis force to cause lateral separation of flow are expected to have near-bottom inflow on the right side and surface outflow on the left side (facing seawards in the Southern Hemisphere). This flow pattern results in sediments deposited on the right flank of ice shelves being higher in biogenic silica and lower in terrigenous sediment in comparison with sediments deposited on the left flank. In this model, the "null zone" of glacial versus marine-sourced sedimentation should trend obliquely across the seafloor beneath an ice shelf or possibly subparallel to the axis of ice flow. Sediments deposited in front of the Vanderford Glacier during the Holocene exhibit higher biogenic silica and lower terrigenous sediment content on the right (eastern) flank compared with sediments deposited on the left (western) flank. This sedimentation pattern is attributed here to the lateral flow separation model of subice-shelf circulation, and such a pattern is expected to occur beneath all ice shelves subject to similar circulation and sediment transport processes.

\section{ACKNOWLEDGEMENTS}

The work described in this paper was financially supported by the Cooperative Research Centre for the Antarctic and Southern Ocean Environment, University of Tasmania, and by the Australian Geological Survey Organisation. Thanks to L. Robertson and S. Woon for assistance in the laboratory and to P. Quilty and two anonymous reviewers for comments on an earlier version of this paper. The author publishes with the permission of the Executive Director, Australian Geological Survey Organisation.

\section{REFERENCES}

Baroni, C. 8 Orombeli, G., 1994: Abandoned penguin rookeries as Holocene paleoclimate indicators in Antarctica. Geology 22: 23-26.

DOMACK, E. \& Harris, P.T., 1998: A new depositional model for ice shelves based upon sediment cores from the Ross Sea and Mac. Robertson Shelf, Antarctica. Ann. Glaciol. 27: $281-284$.

Domack, E.W., Jull, A.J.T., Anderson, J.B., Linick, T.W. \& WILlLAMS, C.R., 1989: Application of tandem accelerator 
mass-spectrometer dating to Late Pleistocene-Holocene sediments of the East Antarctic continental shelf. Quat. Res. 31: 277-287.

Domack, E., O'Brien, P., Harris, P., Taylor, F., Quilty, P., DeSAntis, L. \& Raker, B., 1998: Late Quaternary sediment facies in Prydz Bay, Easr Antarctica: relation to paleo ice shelf grounding line dynamics. Antarct. Sci. 10(3): 236-246.

GOODWIN, I.D., 1988: The nature and origin of a Jokulhaup near Casey Station, Antarctica. J. Glaciol. 34(116): 1-7.

Goon WIN, I.D., 1996: A mid to late Holocene readvance of the Law Dome ice margin, Budd Coast, East Antarctica. Antarct. Sci. 8(4): 395-406.

Harris, P.T., O’Brien, P.E., Srowick, P. \& Truswell, E.M., 1996: Late Quaternary history of sedimentation on the Mac. Robertson shelf, East Antarctica: problems with ${ }^{14} \mathrm{C}$ dating of marine sediment cores. Pap. Proc. R. Soc. Tasm. 130(2): 47-53.

Harris, P.T., Taylor, F., Domack, E., DeSantis, L., Goodwin, I., Quilty, P.G. \& O'Brien, P.E., 1997: Glacimarine siliciclastic muds from Vincennes Bay, East Antarctica; preliminary results of an exploratory cruise in 1997. Terra Antarct. 4: 11-20.

Heier-Nielsen, S., Heinemeier, J., Nielsen, H.L., \& Rud, N., 1995: Recent reservoir ages for Danish fiords and marine waters. Radiocarbon 37: 875-882.

ingolfsson, O., Hjort, C., Berman, P., Bjorck, S., Colhoun, E., Goodwin, I. D., Hall, B., Hrrakawa, K., Melles, M., Moller, P. \& Prentice, M.L., 1998: Antarctic glacial history since the last glacial maximum: an overview of the record on land. Antarct. Sci. 10(3): 326-344.
Leventer, A., Domack, E.W., Ishman, S.E., Brachfield, S., McClennen, C.E. \& Manley, P., 1996: Productivity cycles of 200-300 years in the Antarctic Penninsula region: understanding linkages among the sun, atmosphere, oceans, sea ice and biota. Geol. Soc. Am. Bull. 108(12): $1626-1644$.

Morgan, V. \& van Ommen, T.D., 1997: Seasonality in Late Holocene climate from ice core records. Holocene 7(3): 349-352.

Mortiock, R.A. \& Froelich, P.N., 1989: A simple method for the rapid determination of biogenic opal in pelagic marine sediments. Deep-Sea Res. 36(9): 1415-1426.

O'Brien, P.E., De Santis, L., Harris, P.T., Domack, E. \& QunTY, P.G., 1999: Ice shelf grounding zone features of western Prydz Bay, Antarctica — sedimentary processes from seismic and sidescan images. Antarct. Sci. 11(1): $78-91$.

SHEVEnEl, A.E., Domack, E.W. \& Kernan, G.M., 1996: Record of Holocene palaeoclimate change along the Antarctic peninsula: evidence from glacial marine sediments, Lallemand Fjord. Pap. Proc. R. Soc. Tasm. 130(2): 5564.

Williams, M.J.M., WARnER, R.C. \& Budd, W.F., 1998: The effects of ocean warming on melting and ocean circulation under the Amery Ice Shelf, East Antarctica. Ann. Glaciol. 27: 75-80.

(accepted 5 July 1999) 